\title{
The Syntax and Semantics of Inherent Complement Verbs in Igbo*
}

\author{
Ogbonna Anyanwu \\ Department of Linguistics and Nigerian Languages, University of Uyo, Nigeria \\ Email: ogbonnaanyanwu@yahoo.com
}

\begin{abstract}
This paper examines in some more detail the syntax and semantics of inherent complement verbs in Igbo. This is in addition to Emenanjo (1984, 1986) and Nwachukwu (1987). Here, we have followed Nwachukwu (1987) to assume that inherent complements in Igbo are not the same as the direct objects of transitive verbs. However, contrary to Nwachukwu (1987), it has been observed that there is only a semantic bond between inherent complements and their inherent complement verbs. The bond is not necessarily syntactic. The pronominalization test distinguishes between the objects of transitive verb and inherent complements. Whereas the object complement of transitive verbs can be pronominalized, inherent complements cannot. Contrary to Nwachukwu's (1987) view, it has also observed that there is no movement operation affecting inherent complements when inherent complement verbs license internal arguments. Rather, it is the internally licensed arguments that get raised for feature checking purposes. Also, contrary to the view about Igbo dialects in literature, all Ngwa-Igbo adjectival inherent complement verbs can license internal arguments. The data used in this paper are drawn from the Ngwa dialect ${ }^{1}$ of Igbo which the author speaks with native speaker's competence.
\end{abstract}

Index Terms - inherent complement, inherent complement verb, internal argument, feature checking, licensing, pronominalization

\section{INTRODUCTION}

The terms, 'complementation' and 'transitivity' have been a subject of controversy in Igbo syntax. However, most Igbo scholars (e.g. Emenanjo, 1975 a \& b, 1984, 1986, Ubahakwe, 1976, Uwalaka, 1981, Nwachukwu, 1983, 1984, 1987, Anoka 1983, etc) believe that both terms are relevant in the discussion of Igbo verbs. Emenanjo (1975 a \& b) observes that underlying the semantic import of all verbs is a description of some action or state which involves the presence of certain nominal elements. In fact, in Emenanjo's opinion, all Igbo verbs co-occur with objects of their verbal complex hence they are all transitive. Uwalaka (1981) also notes that the nature of the Igbo verbs in selecting specific nominals has made the definition of Igbo verbs difficult unlike in other languages. Nwachukwu (1987) also recognizes the relevance of transitivity and divides verb in Igbo into transitive and intransitive. He further divides the intransitive verbs into two groups: unaccusatives which introduce a theme argument in object position and unergatives which introduce agent argument in subject position. Nwachukwu also recognizes the sets of intransitives that take inherent complement. Such verbs must co-occur with the complements as are inherent to them. In Nwachukwu's view, the ability or inability of a verb to take an inherent complement is not a yardstick to measure transitivity.

Although transitivity features prominently in the syntax of Igbo, its relevance has become a subject of controversy (Nwachukwu, 1987). For instance, Emenanjo $(1984,1986)$ argues that transitivity is not necessary in the syntax of Igbo verbs since all Igbo verbs obligatorily occur with some complement in both underlying and surface structures. For Emenanjo, transitivity should be likened to a lexical redundancy rule (Radford, 1988); hence it should not be used as a parameter for the classification of Igbo verbs. Emenanjo therefore abandons transitivity as a classificatory criterion and opts for a classification based on complement type. Thus he classifies Igbo verbs into general complement verbs, inherent complement verbs, prepositional complement verbs, ergative complement verbs and bound complement verbs.

Nwachukwu (1987) does not agree with Emenanjo's $(1984,1986)$ classification of verbs based on the kinds of complement they take. Nwachukwu argues that there is no justification for categorization of verbs into general complement verbs, inherent complement verbs, prepositional complement verbs, ergative complement verbs and bound complement verbs. He adds that none of these classificatory parameters is a diagnostic characterization of any semantic class of Igbo verbs; hence they lead to unnecessary cross-classifications. He further adds that every Igbo lexical verb can be made emphatic through the use of a bound complement verb, and as such, this should not be used as a criterion for classification. Just like Uwalaka (1983), Nwachukwu (1987) emphasizes the indispensability of transitivity in Igbo,

\footnotetext{
${ }^{*}$ Ngwa Igbo is the variety of Igbo spoken by an estimated population of about two million people (Nwigwe 1996, Ogbonna 1999) who are located in the sourthern part of Abia State, Nigeria. The area consists of seven Local Government Areas which are Isiala Ngwa North, Isiala Ngwa South, Obingwa, Aba North, Aba South, Osisiọma and Ugwunagbọ.
} 
classifying all Igbo verbs into inherent complement verbs and non-inherent complement verbs. The later he sub-divides into intransitive and transitive.

From the arguments so far presented, it is quite obvious that Emenanjo views transitivity as a purely syntactic phenomenon, while Nwachukwu sees transitivity from a semantic view point. While Nwachukwu's classification is based on transitivity, Emenanjo's is based on complementation. However, none of these two approaches is wrong. Each has something to say about the description of noun phrase and its relationship to the lexical verb, though Nwachukwu's approach is much broader, accommodating both transitivity and complementation. But one fact stands clear despite the divergence in opinion. Transitivity exists in Igbo and it is necessary in the syntax of Igbo verbs. This paper however, is restricted to examining the syntax of inherent complement verbs (ICVs). We shall follow Nwachukwu (1987) to assume that inherent complements are not the same as affected objects of transitive verbs. However, contrary to Nwachukwu's view, we shall argue that there is no movement operation affecting an inherent when the inherent complement verb licenses an internal argument. Also, we shall show contrary to Nwachukwu's view about Igbo dialects that all NgwaIgbo adjectival inherent complement verbs can license internal arguments. The framework adopted here is the principles and parameters (P\&P) approach with special focus on the minimalist program (MP) $)^{2}$. This article is organized as follows. In section 2, I discuss inherent complements in Igbo while Section 3 is the summary and conclusion ${ }^{1}$.

\section{INHERENT COMPLEMENT VERBS IN IGBo}

Nwachukwu (1987) recognizes two types of verb in Igbo. These are inherent complement verbs and non-inherent complement verbs. Inherent complement verbs are subdivided into transitive and intransitive, while non-inherent complement verbs are divided into transitives, unaccusatives and unergatives. He defines an inherent complement verb as a morphological subset of verbs which in its citation form consists of a consonant-vowel (CV) root followed by a free noun (or in very few cases a prepositional phrase). The root and its normal complement form a semantic unit and any dictionary entry which excludes the complement lacks meaning because the complement is the meaning specifying constituent of its verb. He observes that the presence of inherent complements in Igbo has had the effect of complicating the phenomenon of transitivity, since it has led some scholars (e.g. Awobuluyi, 1972, Emenanjo, 1984) to conclude that transitivity is not relevant in the syntax of Igbo and related languages. Nwachukwu argues further that inherent complement is not synonymous with the direct object of transitive verb, since both co-occur. This is not different from our position here. Also, we add that there is only a semantic bond between inherent complement verbs and their inherent complements, since as we shall see later, the inherent complement verbs can license internal NP complements which occur between them and the inherent complements.

\section{A. The Need for Inherent Complements}

The need to expand the functional load of lexically distinct words justifies the existence of inherent complements in Igbo. Hence the inclusion of inherent complements in the Igbo lexicon ensures that there is no increase in the formal lexical units. An inherent complement added to an already existing verb root creates a new lexical item with a new functional semantic load. Just as in other Igbo dialects, the inherent complement in Ngwa, together with its root constitutes a single semantic unit in the lexicon (Anyanwu, 2011). It is important to point out that the functional semantic load of an inherent complement verb rests solely on its inherent complement. This is evident from the fact that the verb root which co-occurs with the inherent complement assumes a different meaning if dissociated from its inherent complement. Examples of inherent complement verbs in Ngwa Igbo include the following:

$$
\text { vu-cluster }
$$

vú-ónū

carry-mouth. IC $^{3}$

'fast'

vù-ivù

get.fat-fat.IC

'be fat'

tu-cluster

tú-l'anyá

hit-at.eye.IC

'be surprised'

(b)

tú-òmú

hit-palmfrond.IC

'summon'

$$
\text { ku-cluster }
$$

\footnotetext{
${ }^{1}$ The minimalist program (MP) is in the current model of Transformational Generative grammar developed by Chomsky (1993, 1995). The MP proposes three major economy principles: Shortest Move, Procrastinate and Greed. The major goal of the MP is to describe the nature of Universal Grammar and as well account for the parametric variations which are manifested by individual grammars.
} 
(a) kú-îu

be bitter-bitter.IC

'be bitter'

(b) kú-égō

make-money.IC

'make money"

(4) ma-cluster

(a) má-ḿmā

be beautiful.IC

be beautiful

(b) má-ḿkpūrú

tie cloth (on body).IC

'tie cloth'

As can be seen from the above examples, some inherent complements are cognate with their verb root (examples, ma-ńmā 'be beautiful', vú-î̃ vù 'be fat') while others are not.

\section{B. The Pronominalization Test}

Pronominalization is a term used in Classical Transformational Grammar to refer to a rule which replaces a lexical NP with a pronoun (Crystal, 1997). Using the pronominalization test, we shall prove that the inherent complement position is never occupied by an object complement of a transitive verb. While the affected object complement of a transitive verb can be pronominalized, an inherent complement cannot. Thus, in Ngwa Igbo, the lexical NP of an affected object can be replaced by the pro-NP constituent, yá 'him/her/it', while the inherent complement cannot. Consider the examples below.

$$
\begin{aligned}
& \text { 5(a) Ezè ǹtù̀ù̀ máni } \\
& \text { Eze pr.libate.past drink.IC } \\
& \text { 'Eze poured a libation' } \\
& \text { (b) *Ezè ǹtừùù ya ya } \\
& \text { Eze pr.libate.past it } \\
& \text { 'Eze libated it' }
\end{aligned}
$$

6(a) Obi ǹvùrù ónú

Obi pr.fast.past mouth.IC

'Obi fasted'

(b) *Obí ǹvùrù yá

Obi pr.fast.past it

'Obi fasted'

7(a) Oojị nà ǹkú í ilú

Kolanut this pr.be.bitter bitter.IC

'This kolanut is bitter'

(b) *Oji nà ǹkú yá

kolanut this Pr-be-bitter IC

'This kolanut is bitter it.

Notice that the (b) sentences in (5-7) above are not grammatical sentences because the inherent complements have been pronominalized. This is unlike the situation in the following sentences $(8-10)$ where the (b) examples are parallel grammatical structures to those in $(5 b),(6 b)$ and $(7 b)$ respectively.
8(a) Ézè ǹtùrù̀ bọólu
Eze pr.throw.past ball.IC
'Eze threw a ball'
(b) Ézè ǹtù̀ù̀ $\quad$ ya
'Eze threw it'
Eze pr.throw.past it
9(a) Âdhá ǹvùrù èkèté
Adha pr.carry.past basket.IC

\footnotetext{
${ }^{2} 3 \mathrm{sg}=3^{\text {rd }}$ person singular pronoun; $2 \mathrm{sg}=2^{\text {nd }}$ person singular pronoun; AGR $=$ Agreement; AGRo = Agreement of object; AGRop $=$ Agreement of object projection; AGRs = Agreement of subject; AGRsP = Agreement of subject projection; AS = Aspectual (Head); ASP = Aspectual Projection; $\mathrm{CV}=$ Consonant-Vowel; IC = Inherent Complement; ICV = Inherent Complement Verb; N = Noun; NP = Noun Phrase; pr = Prefix; Spec = Specifier; $\mathrm{T}=$ Tense $($ Head $) ; \mathrm{t}=$ Trace; $\mathrm{TP}=$ Tense Projection; $\mathrm{V}=$ Verb; VP= Verb Phrase; VR = Verb root.
} 


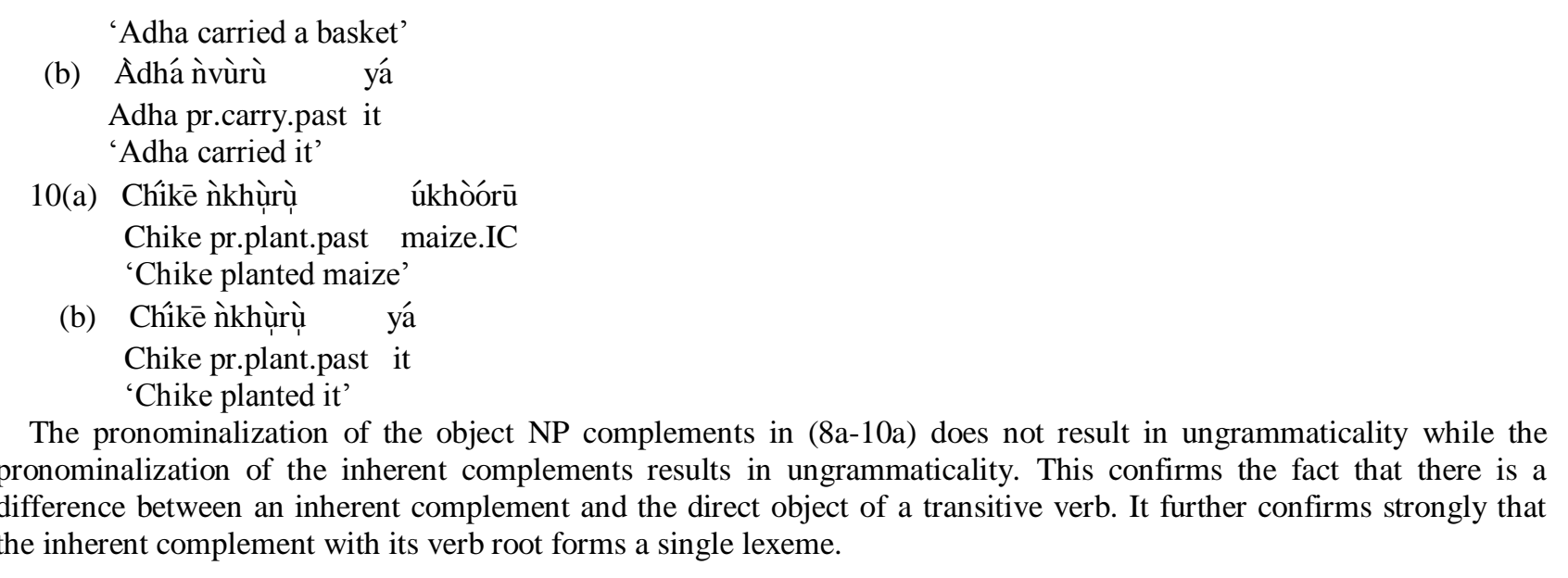

\section{Inherent Complements: A Minimalist Insight}

Nwachukwu (1987) observes correctly that the inherent complement as a zero level category appears in a nonargument position hence; it is invisible to both case and theta role assignment. Also according to him, the inherent complement and its inherent complement verb constitute an $\mathrm{X}^{\mathrm{o}}$ category as shown in the following tree structure (11) where both are under the $\mathrm{V}$ node.

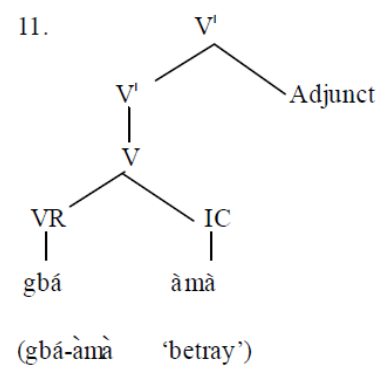

Contrary to Nwachukwu's (1987) view, we want to state here that an inherent complement and its inherent complement verb do not form an $\mathrm{X}^{\mathrm{o}}$ category. The inherent complement and its inherent complement verb constitute a single semantic unit, not a syntactic one. Thus, an inherent complement is not licensed as a constituent under a V-node, but as a constituent within a VP. As a constituent within a VP, its obligatoriness is not of syntactic relevance but of semantic relevance to the inherent complement verb which functions as its head within a VP. More evidence that the inherent complement is only of semantic relevance to the inherent complement verb comes from the fact that the inherent complement cannot be case checked; neither can it be theta-marked. That the inherent complement and its inherent complement verb do not form a syntactic unit will be shown later when we shall show that an internal argument can be licensed between an inherent complement verb and its inherent complement. For now, let us look at how a sentence like (12) with an inherent complement verb is derived as shown in (13).

12 Ézè m̀gàrà àmà
Eze pr.betray.past betrayal.IC
'Eze betrayed (somebody)'

We can observe from the tree structure in (13) that the inherent complement verb 'gbá' merges with the inherent complement 'àmà' forming a V' (V-bar) under the VP node. The agent NP Éż̀ merges with the V (erb) gbá-àmà in order to form the VP Ézè gbá-àmà. The agent NP Ézè, which originates internally in a theta marked specifier position within the VP moves via AGRs into the Spec AGRsP for the purpose of checking its nominative case features. Similarly, the head of the VP, the V moves up into the ASP head slot suffixing the non-perfect marker m (aspectual marker) yielding the complex verbal form which stays at the ASP head slot. As can be noticed in (13), the inherent complement, àmà, though nominal in morphology has no features to check, hence it does not move. 


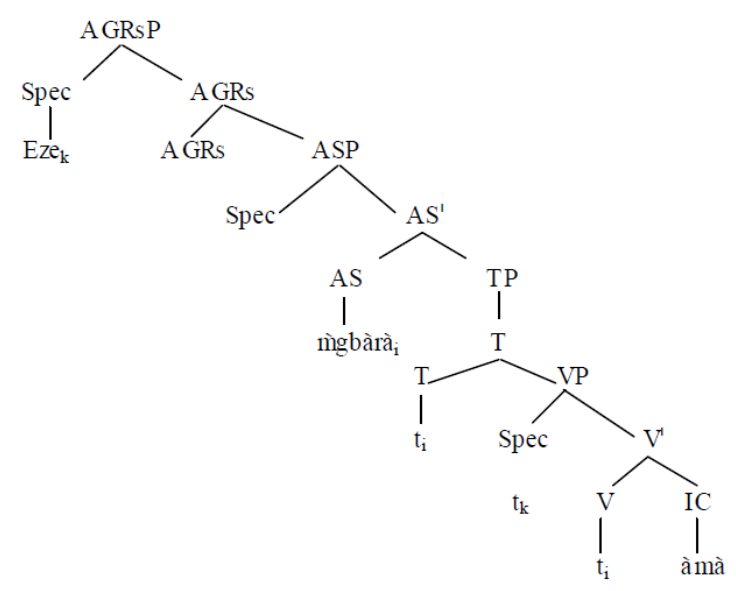

\section{Transitive and Intransitive Inherent Complement Verbs}

Nwachukwu (1987) divides inherent complement verbs in Igbo into transitive and intransitive. A transitive inherent complement verb can license an internal argument complement. It can also case-govern and theta- mark the internally licensed argument. Nwachukwu believes that an intransitive inherent complement verb cannot license an internal argument. Examples of transitive inherent complement verbs are given in (14).

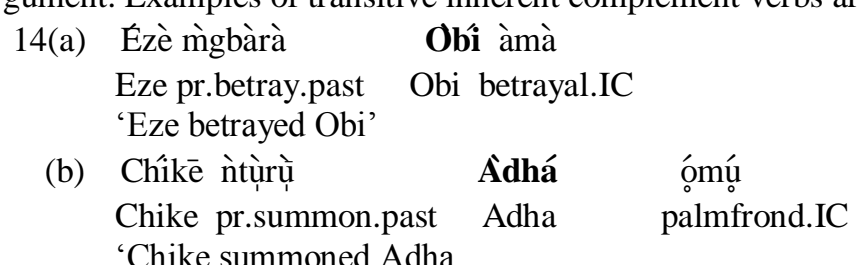

Note in (14a-b) that the internally licensed arguments are Òbí and Àdha'.

On the other hand, Nwachukwu (1987) believes that the inherent complement verbs in (15) can only be used intransitively.
15(i) chá-ùchá as in
(a) Ookúkòo (n)à ǹchá uúchá
fowl this pr.be.white white.IC
This fowl is white
(ii) vù- úvú as in
(b) Ézè ǹvùrù îvu
Eze pr.be.fat fat.IC
Eze is fat
(c) gó-égō as in Tsî̀ yā ǹđì 'ìgō égó
head 3sg. pr.progressiiv.aux. pr.be.black black.IC
$\mathrm{He} /$ her hair is growing black.

The inherent complement verbs in (15) translate into English as be+adjective, hence they can conveniently be labeled as adjectival inherent complement verbs. The nominal complement of such adjectival inherent complement verbs have been described as "qualificative nouns" (Emenanjo 1978) and "qualificative verbs" (Uwalaka 1981), since they form a neat semantic class of stative adjectival verbs each describing an attribute or quality associated with individuals or entities. Nwachukwu (1987) argues further that adjectival inherent complement verbs like the ones in (15) cannot license, govern or theta-mark an internal argument except there is an applicative suffix as in (16).
16 Ookúkòo (n)à ǹchááá
ánỳ̀ ùchá
fowl this Pr.be.white.applicative.suff.past 2pl. white.IC
'This fowl is white for us.

It is, however, possible in Ngwa Igbo for all the adjectival inherent complement verbs to license, govern and thetamark internal arguments without the applicative suffix as the following examples in (17) show where Ėzè and Àdhá have been licensed.
17(a) Ưwéi (n)à ǹchá Ézè ùcha cloth this pr.be.white Eze white.IC 'This cloth makes Eze (look) bright'
(b) Ưwéi (n)à ǹvùrù Âdhá 'ivu
cloth this pr.be.fat Adha fat.IC
'This cloth made Adha (look) fat' 
It is however, observed from (17) that when an adjectival inherent complement verb licenses an internal argument, the sentence has a causative reading. Nevertheless, the adjectival inherent complement verb governs and theta-marks the licensed argument. The implication here is that the sharp contrast between transitive and intransitive or division of verbs into transitive and intransitive is misleading. In fact, it has been stressed in the literature that transitivity should be regarded more or less as a scalar notion (Osam, 2000), so that verbs can be put on a scale or graded in terms of transitivity.

\section{E. The Inherent Complement and Internally Licensed Argument}

Nwachukwu (1987) is of the view that there is a move-a (movement) operation which applies obligatorily when a transitive inherent complement verb licenses an internal argument. This move- $\alpha$ operation he refers to Move-IC, since accordingly to him, the inherent complement in such constructions moves, being displaced by the internal argument. Consider the following examples that follow.

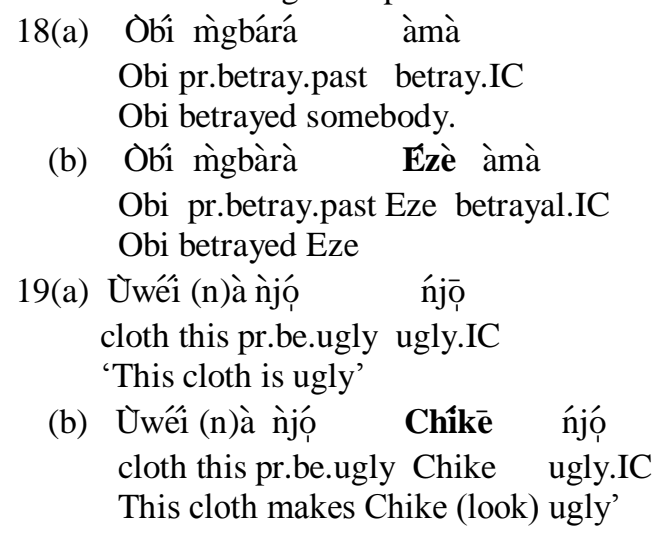

In examples (18a) and (19a), the inherent complement verbs migbàrà, njó and their respective inherent complements àmà, njó occur strictly adjacent to each other, while in (18b) or (19b), there is an internal argument (Ézè or Chíkē), licensed by the inherent complement verb which according to Nwachukwu intrudes into the position between the inherent complement verb and the inherent complement moving the inherent complement rightwards in order to allow strict adjacency between the inherent complement verb and the internally licensed argument. This movement of the inherent complement, as conceived by Nwachukwu, is diagrammatically shown in (20) below using the construction in (18b).

However, the movement of the inherent complement, àmà, as shown in the structure (20) is not well motivated for a number of reasons. First, movement of constituents in Igbo (SVO) is always not rightwards, but leftwards, closer to functional heads for the purpose of feature checking. Secondly, the inherent complement àmà, which appears in a nonargument position has no case features to check; hence, by economy principle (movement can only take place when necessary) cannot be raised to any point in the derivation.

20

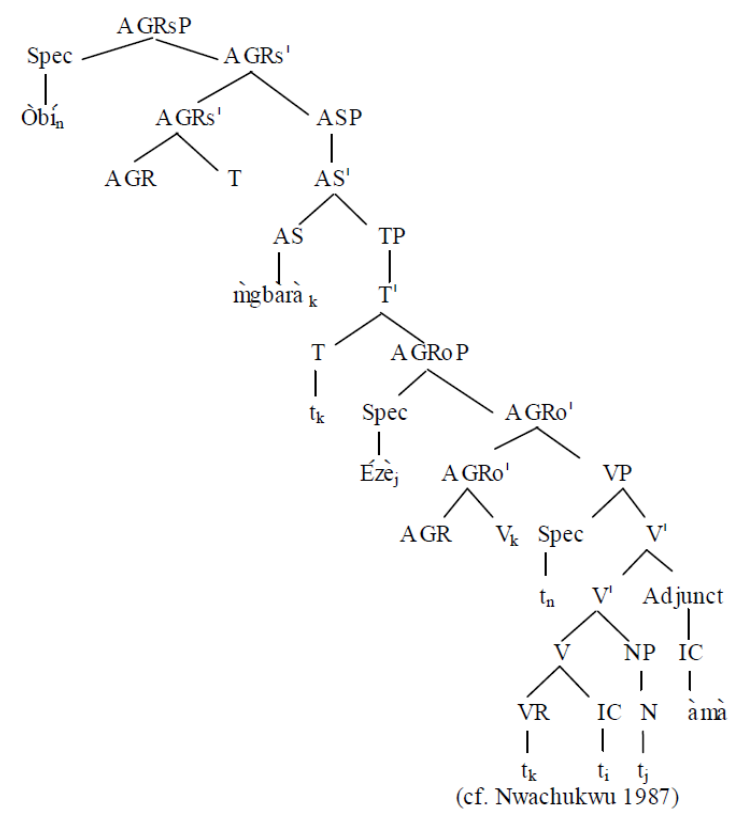


Based on the reasons given above, I have presented an alternative derivational analysis. I have also used the construction in (18b) repeated here as (21).

21 Obì mìbàrà Ézè àma

Obi Pr-witness-FACT Eze IC

Obi betrayed Eze

Let us assume that the verb' mgbàrà is merged with the inherent complement, àmà to form the $\mathrm{V}$ mgbàrà- àmà, while the resulting V then merges with the NP Ézè to form the VP in (22).

22

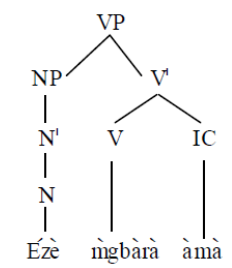

The VP in (22) further merges with AGRo forming the related AGRo' projection. Subsequently, the verb migbàrà raises to AGRo, while the NP Eźè raises to the Spec of AGRoP yielding the derived structure (23).

23

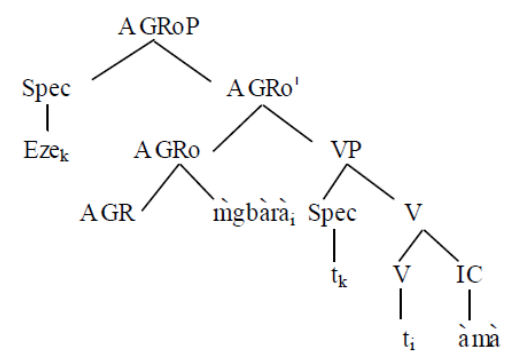

The NP Éżè and AGRo (at this stage of the derivation, AGRo houses the verb) are in a Spec-head relationship, hence the objective case feature of Ezè is checked against that of the AGRoP constituent of (23) and then merged with an abstract performative light verb (cf. Radford, 1997) whose Spec position contains the agent NP Òbí. The verb migbàrà further raises from AGRo into the head position of the abstract performative light verb. From here, the verb raises into the head of TP and to the head of ASP checking and activating its tense and aspectual features respectively. Finally, the agent, Òbí in the Spec position of the abstract performative light verb raises into Spec AGRsP, checking its nominative case features as shown in (24).

24

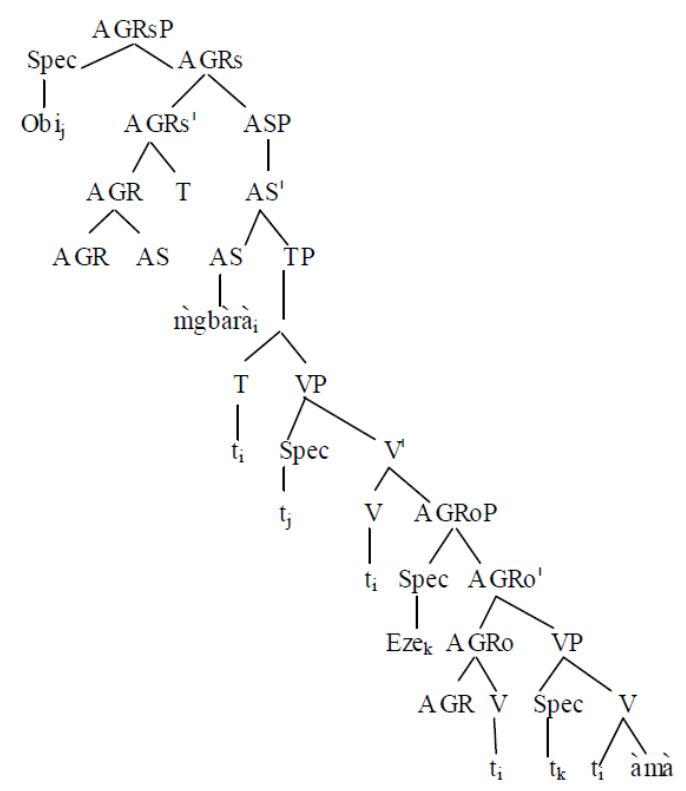


Note again that the inherent complement àmà does not raise to any position. This is in fulfillment of the economy principle since it has no feature to check. Also, contrary to Nwachukwu's view, the landing site for the inherent complement is not an adjunct position. Adjunct positions house optional elements of clause structure whose omisibility does not result in ungrammaticality. The inherent complement is within the VP, and not in an adjunct position since its omissibility does result in ungrammaticality as examples (25) show. The inherent complement maintains an obligatory semantic link with its inherent complement verb which functions as the head of the VP projection.

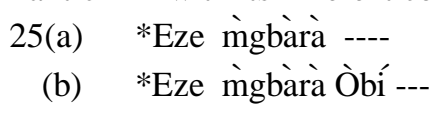

\section{Summary AND CONCLUSION}

In the course of this paper, we have come to the conclusion that the bond between the inherent complement verb and its inherent complement is essentially semantic. Thus, the inherent complement verb with its inherent complement constitutes a semantic unit and not a syntactic one. Contrary to Nwachukwu's (1987) view, the inherent complement verb and its inherent complement do not constitute an $\mathrm{X}^{\circ}$ category. This claim is supported by the fact that, the syntactic link between the inherent complement verb and its inherent complement can be broken by an internally licensed argument. Thus the obligatoriness of the inherent complement in a VP is semantically relevant to the inherent complement verb, which functions as the head of the VP. Following Nwachukwu (1987), we assume that the inherent complement as zero level category appears in a non-argument position. However, contrary to his claim, there is no movement operation affecting the inherent complement. Rather, an internally licensed argument in an inherent complement verb construction raises for the purposes of checking its objective case features. Our argument against positing an inherent complement movement being that there is no motivation for such movement since it is not feature driven. If the inherent complement must move, it must be for reasons of feature checking. We however, observed that the inherent complement is visible to both case and theta-role assignment.

Finally, contrary to the view in the literature about Igbo dialects, all Ngwa adjectival inherent complement verbs can license an internal argument.

\section{REFERENCES}

[1] Anoka, G.M.K. (1983). Selectional Restrictions: Verb “to buy.” In Nwachukwu, P.A. (ed.) Readings on the Igbo Verb. Onitsha: African Publishers Ltd. 25-41.

[2] Anyanwu, O, N. (2011) .The syntax of Ngwa Igbo causatives: A minimalist approach. Saabrucken: Lambert Academic Publishing.

[3] Awobuluyi, O. (1972). On the classification of Yoruba Verbs. In Bamgbose, A. (ed.) The Yoruba Verb Phrase 49-68. Ibadan: Ibadan University Press.

[4] Crystal, D. (1997). A dictionary of linguistics and Phonetics. London: Basil Blackwell.

[5] Chomsky, N. (1993). A minimalist program for linguistic theory, In Hale, K. And S.J. Keyser (eds.). The view from building 20: Essays in linguistics in honour of Sylvain Bromberger. Cambridge, Mass: MIT Press. 41-58.

[6] Chomsky, N. (1995). Bare phrase structure. In Webelhuth, G. (ed.). Government and binding theory and the minimalist program. Cambridge: MIT Press.383-4.

[7] Emenanjo, E.N. (1975a). The Igbo Verbal: A Descriptive analysis. M.A. Thesis, University of Ibadan, Nigeria.

[8] Emenanjo, E.N.(1975b). Central Igbo-An Objective Appraisal. In Ogbalu, F.C., and E.N. Emenanjo(eds.) Igbo Language and Culture 56-70. Ibadan: Oxford University Press.

[9] Emenanjo, E.N.(1978). Elements of Modern Igbo Grammar. Ibadan: Oxford University Press.

[10] Emenanjo, E.N.(1984). Igbo Verbs. Transitivity or Complementation? A paper presented at the $5^{\text {th }}$ Annual Conference of the Linguistics Association of Nigeria, Nsukka.

[11] Emenanjo, E.N.(1986). Igbo Verb Complements and the Argument Structure of Compounds, Linguistics 260 Talk. Harvard University, March, 1986.

[12] Nwachukwu, P.A. (1983). Transitivity. In Nwachukwu P.A. (ed) Readings on the Igbo Verbs 23-55. Onitsha: African Publishers Ltd.

[13] Nwachukwu, P.A. (1984). Stative Verbs in Igbo Syntax. Journal of linguistic Association of Nigeria 3,61-74

[14] Nwachukwu,P.A. (1987). Argument Structure of Igbo Verbs. Lexicon project. Cognitive science centre, MIT.

[15] Osam, K. (2000). Transitivity and reflexivisation in Akan. Paper presented at the 22nd West African Languages Society, held at the University of Ghana, Legon.

[16] Radford, A. (1988). Transformational Grammar. Cambridge: Cambridge University Press

[17] Radford, A.(1997). Syntax: A Minimalist Introduction. Cambridge: Cambridge University Press

[18] Ubahakwe, E. (1976). On The Question of Transitivity and Intransitivity in Igbo Verbs. Odenigbo 1, 45-65.

[19] Uwalaka, A. (1981). The Syntax and Semantics of Igbo Verbs: A Case Grammar Analysis. Ph.D. Dissertation, University Ibadan.

[20] Uwalaka, A. (1983). Some Problems Relating to Igbo Verbal Studies. In Nwachukwu, P.A. (ed.) Readings on Igbo Verb $42-57$. Onitsha: African Publishers Ltd. 
Ogbonna Anyanwu is a Senior lecturer at the Department of Linguistics and Nigerian Languages, University of Uyo, Nigeria. He obtained his MA and $\mathrm{PhD}$ degrees from the University of Port Harcourt, Nigeria. His research interests include phonology, morphology, Igbo syntax and the development of non-major Nigerian languages. He has published mainly in these areas. 